\title{
On International Scientific Seminar "Russian Traditionalism: History, Ideology, Poetics, Literary Reflection" that Took Place in Siberian Federal University on 16-19 November 2015
}

\author{
Natalia V. Kovtun* \\ Siberian Federal University \\ 79 Svobodny, Krasnoyarsk, 660041, Russia
}

Received 17.09.2015, received in revised form 24.11.2015, accepted 03.12.2015

\begin{abstract}
The paper analyses the work of International Scientific Seminar "Russian Traditionalism: History, Ideology, Poetics, Literary Reflection" held within the Year of Literature in Russia on 16-19 November in Siberian Federal University. The major aims of the forum are: to define the place of the traditionalist literature in the history of the contemporary Russian prose and classical literature in general, as well as in the socio-cultural context of the beginning of the 21st century; to develop heuristic approaches to the interpretation of the traditionalist style of creative writing; to popularize the texts of the traditionalist Russian prose in Russia and other countries. In addition, the aim of the project is to develop and improve scientific and cultural environment of the Krasnoyarsk Territory, rationale of the high importance of the artistic heritage collected in the region, the necessity for its scientific study and promotion. Representatives of academic and university science from the leading Russian and European universities took part in the forum. The forum was held with the support of the Ministry of Culture of the Krasnoyarsk Territory, Society "Znanie" of Russia, Association of Teachers of the Russian Language and Literature of Higher School, Siberian Federal University, Astafiev's Scientific and Research Centre of Siberian Federal University and Open International Scientific Society "Russian Language and Literature: Spiritual and Cultural Contexts".
\end{abstract}

Keywords: forum "Russian Traditionalism", the Year of Literature, Society "Znanie" of Russia, Siberian Federal University.

DOI: 10.17516/1997-1370-2015-8-12-2989-2995.

Research area: philology.

Within the Year of Literature in Russia on 16-19 November International Scientific Seminar "Russian Traditionalism: History, Ideology, Poetics, Literary Reflection", organized with the support of the Ministry of Culture of the Krasnoyarsk Territory, Society "Znanie" of
Russia, Association of Teachers of the Russian Language and Literature of Higher School, Siberian Federal University, Astafiev's Scientific and Research Centre of Siberian Federal University, Open International Scientific Society "Russian Language and Literature: Spiritual

(C) Siberian Federal University. All rights reserved

* Corresponding author E-mail address: nkovtun@mail.ru 
and Cultural Contexts" and leading Russian and European universities took place in Siberian Federal University. Only for the last two years it is the third large philological forum for Siberian Federal University. At the end of 2013 with the support of the largest scientific foundations (The Mikhail Prokhorov Foundation and The Dmitri Prigov Foundation) International Scientific Conference "Crisis of Literary Centrism: Loss of Identity vs. New Opportunities" was held, and after the conference a monograph that got good reviews both in Russia and other countries (Crisis of Literary Centrism, 2013) was published. This summer our colleagues - economists organized a seminar for the best translators and interpreters of Russia and Europe, who work with Russian texts and, finally, this seminar encouraged the discussion about traditionalism that is more and more contradictory interpreted by the authors of this style and their critics - literary scholars (Kovtun, 2009; Razuvalova, 2015).

We would like to emphasize that the interest to the poetics of traditionalism also distinguishes European culture today, which is connected with disillusionment in the ideology of globalism and closing Post-Modernism project. Thus, in September 2015, Georgia hosted the International Symposium "Tradition and Modern Literature" (Shota Rustaveli Institute of Georgian Literature, Georgian Comparative Literature Association (GCLA)), where the issues of preservation and transmission of traditions, their status in the contemporary world, the importance of translation activities, aimed at cultural approximation of nations were raised.

The opening ceremony of the forum in Siberian Federal University started with the welcoming speeches of the Deputy Chairperson of the Krasnoyarsk Territory Government Natalia V. Ryazantseva, Vice-Rector for Research and International Cooperation of Siberian Federal University Sergey V. Verkhovets, Chairperson of the Executive Committee of the Association of Teachers of Russian Language and Literature of Higher School Liubov' V. Farisenkova (Moscow) and Director of Diocesan Educational Centre of the Krasnoyarsk Eparchy Andrei V. Bardakov. Welcoming speeches ended with the speeches of the Academician of Independent Academy of Aesthetics and Liberal Arts, Chief Researcher-Consultant of St. Petersburg Institute of History of the Russian Academy of Sciences Boris F. Egorov and Chairperson of Krasnoyarsk Regional Branch of the Association of Teachers of Russian Language and Literature of Higher School Natalia V. Kovtun.

All the speakers pointed out that the issue of the status and artistic features of the contemporary Russian traditionalism is still controversial, and it is important to understand why at this precise time discussion concerning this phenomenon is particularly fierce. A few years ago traditionalism was talked about as a provincial style of our literature, the writers of the style were read and published much less, but the end of the era of Post-Modernism facilitated realistic principles of writing, the idea of national identity, traditions, memory and roots. We can not say that today's generation massively started reading the books by V. Belov, V. Astafiev, V. Rasputin, V. Lichutin ... It is not happening, and at the same time, themes, motifs and images that the aforementioned authors introduced into the cultural field are becoming popular, although sometimes their meaning is leveled, degenerating into the sign. From the semiotic arsenal of traditionalism Z. Prilepin, M.A. Tarkovsky, R. Senchin partially build their oecumenes, playing with the idea of continuity. How promising the dialogue of generations is, how far we are ready to read well-known authors in the changed context and, what, in fact, is contemporary Russian traditionalism, how the authors of this style are perceived in Russia and in the West - these are the main issues that were 
raised by the participants of the international seminar.

Special importance of the forum is determined by several factors. Socially, the past seminar and open lectures given by its participants, contribute to the alleviation of the acuteness of the humanitarian problem of the cultural intellectual environment weakening both in the Krasnoyarsk Territory, and Russia as a whole by involving the largest possible number of people to discuss the issues of national identity, national traditional culture, artistic life in Siberia and its role in the history and culture of the country. Arousing interest to the work of traditionalist writers, we update the quality parameters of moral, aesthetic and patriotic education and contribute to the formation and establishment of regional and national identity.

From the strictly scientific point of view the study of fictional traditionalism gives possibility to reveal the corpus of ideas, mythologemas and archetypes that form the core of the national identity, to conceptualize the history of this literary style formation and development; to describe the models of connection of literary eras to tradition, their importance for the characteristics of a literary period and understanding the tradition by the literature of the turn of the $20^{\text {th }}-21^{\text {st }}$ centuries: (re[de]construction of the concept of "tradition" in the era of globalization).

In the course of the seminar the phenomenon of creative life and the system of cultural and behavioral "gestures" of traditionalist writers as well as aesthetics, poetics and problematics of these authors' works were discussed. The ways of perception of Russia and "Russian" in the creative work of the traditionalists and theoretical problems of reception as a way of reproduction, the "invention" of artistic and aesthetic traditions in classical and post-classical period of Russian literary history are of significant interest. National and regional aspects of creative work of
V. Shukshin, V. Astafiev, V. Rasputin, V. Lichutin, M. Tarkovsky and R. Senchin are of particular importance.

The workshop gave possibility to consider the problem of Russian traditionalism reception in the European cultural community: postulating the correct orientations of perception and evaluation of the traditionalist Russian text, its translation and forms of dissemination. To solve this problem, the experts who study the creative work of the traditionalists in the modern international reception (translations, criticism and research) and who are developing methods of modern traditionalist literature promotion in the cultural sphere of the European community to form adequate and deep understanding of the fundamentals of Russian civilization were invited.

The successful format of the seminar should be noted particularly: more than 30 doctors of sciences, who study the problematics of traditionalism in its various aspects (from the issues of poetics to the sociology of literature and gender studies) were invited to Siberian Federal University. The highest professionalism of the participants also contributed to the level of scientific debate. The plenary session was quite agitated. I. L. Bagration-Mukhraneli (St. Tikhons' Orthodox University of Humanities) opened the seminar with the report on "Motive Structure as a Way of Tradition Transmission", devoted to the theory of literature. N.V. Kovtun outlined the prospects of traditionalism transformation at the turn of the $20^{\text {th }}-21^{\text {st }}$ centuries, having demonstrated not only topicality of this style in the modern literature, but as the latest ideas of time and space were embodied in the texts of the traditionalist writers a long time before their grounding in exact sciences.

The report of an outstanding Russian scientist Boris F. Egorov at the Plenary Session evoked great interest. He pointed out that half a 
century ago, he wrote: "Culture and science can exist only in the presence of memory" and the rest of his life he has been repeating the aphorism "Culture is memory". And traditionalism being the core of this scientific forum, is the most important part of the historical memory. A great variety of reports on the main topic of the seminar well demonstrates the thesis "Culture is memory". Let us emphasize that for literature experts of Siberian Federal University collaboration with B.F. Egorov has become a tradition. In 2011, the joint effort of scientists resulted in the monograph "Russian project of improving the world and artistic creativity of the $19^{\text {th }}-20^{\text {th }}$ centuries" (Russian Project, 2011).

All speakers at the seminar talked about the importance of the category of tradition, traditionalist literature and the humanities in general for the development of the modern society. They outlined the close connection of literature, culture and socio-economic processes. The report of Anna I. Razuvalova (The Institute of Russian Language and Literature of Russian Academy of Sciences, the Pushkin House) "Nationalists Traditionalists - Reactionaries: to the Problem of National-Conservative Forces Self-Naming (the 1990-2000s)" resulted in a dispute, while it was prepared in the paradigm of literature sociology and not poetics. Nevertheless, it is this field in which the issues broadening the understanding of tradition, its interpretation in all areas of culture and for various purposes (from politics and ideology to philology) appear. Natalia S. Tsvetova (Saint Petersburg State University) and Tatiana A. Ternova (Voronezh State University) in their reports touched upon the urgent issues of the intertextual motifs in the traditionalist prose and demonstrated the history and dynamics of the establishment of this trend.

Tatiana A. Kruglova (Ural Federal University named after the First President of Russia B.N. Yeltsin) and B.F. Egorov in their reports indicated the specificity of the cultural situation in the early 1960s, when the Soviet canon was still significant at the metropolis level, and at the same time the "village prose" that gave the Russians the idea of their roots, traditions and national faith appeared. The topics raised, profoundly affected each member of the Scientific Forum, there were a lot of questions and scholarly discussions, which continued after the end of the plenary session. It is extremely important that the first day set the scope of relevant topics and urgent issues that had been analyzed during the four days of hard work, and will be certainly studied further by every scientist in the future.

During the second day the panel sessions "Traditionalism Axiology in the Context of Literature of the 19 $9^{\text {th }}$ Early $20^{\text {th }}$ Centuries" and "Traditionalist Writers: Special Aspects of Artistic Dialogue" took place, in total there were more than 15 presentations, which caused a lively discussion. The sessions were marked by an appeal to the creativity of the writers of the late $19^{\text {th }}$ - early $20^{\text {th }}$ centuries. A number of reports were devoted to the works of Andrei Platonov, whose path from the idea of revolution and utopian transformation of the world to the values of the Old ("The Pit") and the New Testament (military prose, "The Return") is very remarkable. Yanina V. Soldatkina (Institute of Philology and Foreign Languages of MSPU) in the report “A. Platonov's Traditions in the Modern Prose (A. Varlamov 'The Imagined Wolf' and A. Ivanov 'Bad Weather')" traced the influence of Platonov's prose on the current Russian literature.

The day finished with a report based on a thorough analysis of the unique archival heritage of A.I. Solzhenitsyn. G.A. Tyurina and I.E. Melent'eva of the House of Russian Abroad by the Name of A.I. Solzhenitsyn not only delivered interesting reports, but also brought unique books related to the study of the heritage of the writer with them. Some of the gift books 
were donated to the State Scientific Library of the Krasnoyarsk Krai. It was here, in anticipation of the International Scientific Seminar when B.F. Egorov began delivering open lectures devoted to the tragic poets of the $20^{\text {th }}$ century.

The panel session "Modern Traditionalism: Ideology and Mythopoetics" set the tone for the scholarly discussion of the third day of the Seminar. A significant set of reports was devoted to the analysis of the prose V. Astafiev. The variety and conceptuality of approaches caused an extremely productive discussion. For the Seminar being held at the writer's Siberian homeland, such attention paid to his works is particularly significant. Tamara A. Nikonova (Voronezh State University) in her report “Writer's Biography as Literary Reflection: A. Solzhenitsyn, V. Astafiev, $V$. Rasputin" analyzed the authors' myths that seriously affected the perception of their prose. Alexander I. Kulyapin (Altai State Pedagogical University) made a kind of an "amusing" report "Space Topic in the Prose of Traditionalist Writers (Y. Nosov, V. Shukshin, V. Astafiev)" demonstrating the originality of artistic worlds of the prose writers through the interpretation of the key themes: city-village, attitude to the progress, achievements of civilization.

One of the most insightful reports "The Eternal Femininity in Natural-Social Conception of V. Astafiev" was presented by Irina I. Plekhanova (Irkutsk State University). She deployed the essence and evolution of Astafiev's understanding of the key aspects of the topic of the Eternal femininity as the philosophical idea of the author. The writer reflected the national tradition in the archetypal and historical content. The researcher found out the degree of the author's closeness to the intellectual development of the idea and imaginative tradition of its experiencerepresentation. Nina P. Khriashcheva (Ural State Pedagogical University) in her report "The Problem of Genre Synthesis in 'Ode to Russian
Vegetable Garden' by V.P. Astafiev", Alexander V. Kubasov (Ural State Pedagogical University) in his report “'Zatesi' by V.P. Astafiev as a Type of a Siberian Text" and Tamara Y. Klimova (EastSiberian State Academy of Education) in her report "'The Jolly Soldier' by $V$. Astafiev in the Paradigm of 'Human Peacefulness' and 'Human Dimension" and other speakers dwelled on the artistic features and poetics of V.P. Astafiev.

In the second half of the day, pronounced attention was paid to the works of V. Rasputin, the recognized leader of this school. The researchers focused mainly on the characterology and the chronotope of the author's prose. A famous researcher of the writer's heritage Alexander A. Dyrdin (Ulyanovsk State Technical University) presented "National Identity of V. Rasputin's Characterology (Novel 'Live and Remember')"emphasizing not just the central place of female characters in the artistic world of the writer, but showing them in dynamics (from the images of a wise old woman, female victims to the defenders of land and family in his later works). Vasilina A. Stepanova (Siberian Federal University) in her report "The Chronotope of V. Rasputin's Prose" and Mika Perkiomäki (Tampere University, Finland) in the report "The Image of River in V. Rasputin's Creative Work (Feature Story 'Up and Down the Stream')" correlated the study of the writer's prose with the Russian philosophical tradition and European environmental school, which has just appeared in Russia.

At the same time, there was the panel session "Traditionalist Writers in the Mirror of Literary Criticism and Comparative Studies". The reports presented at the session included three quite clearly determined problem groups: reports on the analysis of critical articles about the prose traditionalist writers; reports related to the study of historiography and strategies of transmitting traditionalist texts in other languages 
and cultures and reports related to the issues of comparative linguistics. Leonid P. Bykov (Ural Federal University named after the First President of Russia B.N. Yeltsin) opened the session with the report “'Thick Journal' in Russia: Yesterday, Today, Tomorrow" dedicated to the diachronic consideration of the fate of "the thick journal" as a unique phenomenon of the Russian culture of the $19^{\text {th }}-20^{\text {th }}$ centuries. Elena A. Andreeva appealed to the understanding of traditionalism as an effective interpretive strategy in literary criticism.

The translation section of the panel session presented urgent problems of preservation of Russian and, in particular, Siberian cultural information and memory in the situation of the interlingual translation of the texts of modern traditionalists: V. Rasputin's texts into French, as Vera E. Gorshkova (MSLU EALI, Irkutsk) outlined in her speech "Modern Russian Traditionalism in French Translations"; V. Astafiev's texts into European languages (the report of Veronica A. Razumovskaya (Siberian Federal University) "The Texts of Russian Traditionalism in Translations: A Case Study of $V$. Astafiev") and into Chinese (the report of Valentina V. Nikitenko (Siberian Federal University) "The Russian Culture in the Mirror of Chinese Literature and Translation ('Tsar Fish' by V. Astafiev)". The reports of the specialists of Siberian Federal University devoted to literary comparative studies investigating the synthesis of the classic and contemporariness in the texts of German (Tatiana S. Nipa, "Synthesis of Archaism and Modernity in 'Antique' Dramas by G. Hauptmann") and French (Vladislav E. Biktimirov, "Fictional Interpretation of the Plot about Amphitryon in J. Giraudoux and P. Hacks' Plays") drama aroused great interest among the audience. Scholarly discussion at the end of the session was intensive and constructive, each report presented a prospective study of a significant theoretical and practical value.

The International Scientific Seminar finished with the open lectures of B.F. Egorov "Poems in GULAG" and G.A. Tyurina "Life and Poetry is the Same: on the Basis of Aleksandr Solzhenitsyn's Archive". The lectures were so spectacular that the participants needed more time to discuss the new material. In the afternoon, the participants went on a tour to Ovsyanka, home village of V.P. Astafiev.

Guests and participants of the Seminar were invited to an exhibition of books on the problems of modern traditionalism. It is extremely significant that almost all authors responsible for editing monographs and collections of research papers participated in the forum. Upon the results of the conference, it is planned to publish a monograph, which will continue the scholarly dispute and include the widest range of urgent topics for researchers studying traditionalism.

\footnotetext{
In the course of the project implementation the funds of the government support, appropriated as a grant in accordance with the Decree of the President of the Russian Federation dated 01.04.2015 № 79-pп and on the basis of the competition held by Society "Znanie” of Russia are used.
}

\section{References}

Kovtun, N.V. 'Derevenskaia proza'v zerkale utopii ['Village Prose' in the Mirror of Utopia]. Novosibirsk, 2009.

Krizis literaturotsentrizma: utrata identichnosti vs. novye vozmozhnosti [Crisis of Literocentrism: Loss of Identity vs. New Opportunities]. Executive editor N.V. Kovtun. Moscow, 2013.

Razuvalova, A.I. Pisateli- 'derevenshchiki': literature i konservativnaia ideologiia 1970-kh godov [Village Prose Writers: Literature and Conservative Ideology of 1970-s]. Moscow, 2015. 
Russkii proekt ispravleniia mira i khudozhestvennoe tvorchestvo X1X-XX vekov [Russian Project of Improving the World and Artistic Creativity of the $19^{\text {th }}-20^{\text {th }}$ Centuries]. Executive editor N.V. Kovtun. Moscow, 2011.

\title{
О Международном научном семинаре «Русский традиционализм: история, идеология, поэтика, литературная рефлексия", прошедшем в Сибирском федеральном университете 16-19 ноября 2015 года
}

\author{
Н.В. Ковтун \\ Сибирский федеральный университет \\ Россия, 660041, Красноярск, пр. Свободный, 79
}

Статья посвящена анализу работы Международного научного семинара «Русский традииионализм: история, идеология, поэтика, литературная рефлексия», прошедшего в рамках Года литературы в России 16-19 ноября в Сибирском федеральном университете. Основная цель форума: определение места традиционалистской литературы в истории современной русской прозы и классической литературы в целом, а также в соииокультурном контексте начала ХХІ века; выработка эвристических подходов к интерпретации традиционалистского модуса творчества; популяризация текстов русской традиционалистской прозы в России и за ее пределами. Кроме того, целью проекта является развитие, совершенствование научной, культурной среды Красноярского края, обоснование высокой значимости художественного наследия, собранного в регионе, необходимости его научного изучения и продвижения. В работе форума принимали участие представители академической и вузовской науки из ведущих университетов России и Европь. Форум получил поддержку Министерства культурь Красноярского края, общества «Знание» России, Ассоџиаџии преподавателей русского языка и литературы высшей школь, Сибирского федерального университета, Астафьевского научно-исследовательского иентра Сибирского федерального университета, Открытого Международного научного сообщества «Русская словесность: духовно-культурные контекстыл».

Ключевые слова: форум «Русский традиционализм», Год литературы, общество «Знание» России, Сибирский федеральный университет.

Научная специальность: 10.00.00 - филологические науки. 